\title{
The Story of Turkestan: Ethnic Distinction of Kazakhs in European Written Sources
}

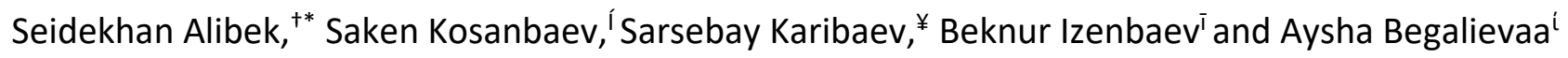

\section{Abstract}

This research aims to examine the ethnographic data about the Kazakh ethnic group from the European sources of the middle XIII to early XX centuries. The study uses problem-chronological and comparative-historical analyses to process data published by European travellers, merchants, soldiers and scientists. The European works contain factual inaccuracies, unverified information and speculations. Their quality has improved since the XVIII century though. The findings of European explorers allow a better understanding of the ethnogenesis of Kazakhs and their transition to statehood. Data available in these sources will help find the historical roots of contemporary ethnic and inter-ethnic problems in Kazakhstan and Central Asia. The present study allowed a look at the past life of Kazakh people and their ethnic distinction in Turkestan through the lens of European mentality.

Keywords: Kazakhs; Kyrgyz; Turkmen; Ethnicity; Ethnogenesis; Nation; Nomads; Traditions; Turkestan; Central Asia

\footnotetext{
${ }^{+}$M. Auezov South Kazakhstan State University, Kazakhstan

${ }^{*}$ Corresponding Author, Email: seidekhan_alibek@yahoo.com

'M. Auezov South Kazakhstan State University, Kazakhstan, Email:sakkosanbaev999@bk.ru

${ }^{¥}$ M. Auezov South Kazakhstan State University,Kazakhstan, Email:sarsebay_kari@mail.ru

'L.N.Gumilyov Eurasian National University, Kazakhstan, Email: b.izenbaev5@rambler.ru

'Al-Farabi Kazakh National University, Kazakhstan, Email: ayay.begalieva83@mail.ru

(C) 2020 Alibek et al. This is an Open Access article distributed under the terms of the Creative Commons Attribution License (http://creativecommons.org/licenses/by/2.0), which permits unrestricted use, distribution, and reproduction in any medium, provided the original work is properly cited.
} 


\section{Introduction}

The ethnicity and nationhood in Central Asia came a long and thorny way to be. The fascinating history of challenges that came along with the ethnic identity formation in many countries of Central Asia including Turkestan knows a number of groundbreaking events that manifested in the way these countries build their international relations today. The historic geographical borders of Turkestan are challenging to distinguish. Back in the day, the area of Turkestan was somewhat stretched, as compared to borders today, and covered some of the territories of Kazakhstan, Kyrgyzstan, Uzbekistan, Tajikistan and Turkmenistan, the Xinjiang Uygur Autonomous Region, South Siberia, Northern Afghanistan, and Iran (Liedy, 2011; Morrison, 2015). Reconstructing the ethnogenesis of Asian peoples is challenging, considering the scale of historicalcultural research. That is to say, Kazakhs living within the territory of Turkestan belong to the ethnic group that is among the most ancient, numerous and widely distributed ethnic groups in Central Asia (Chan, 2016; Islam, 2016; Starr, 2015).

This problem-chronological study is a review of the early ethnographic records made by European travellers, soldiers and scientists. The records encompass territories, traditions and customs that constitute the ethnic Kazakh community. The study used a comparative historical method of research to identify attributes of the ethnic identity of Kazakhs and determine the scientific value of records under study.

The understanding of the traditions of Kazakhs will allow avoiding the emergence of new and exacerbation of old ethnic problems when communicating with actors in the New Great Game and the New Silk Road project. The earlier specified range of knowledge will help Kazakhstan, and other former-Soviet Central Asian republics harmonise their inter-state relations at the time of geopolitical turbulence.

The novelty of this study lies in the fact that it conducts a complex exploration of European literary and scientific works about the ethnogenesis of Kazakhs. The present findings will enrich the knowledge of the ethnic development of Kazakhs and Kazakh statehood in the middle of the XIII to the beginning of XX centuries.

The study begins with a brief review of the literature. Following this, it critically analyses the findings.

\section{Literature Review}

Today's research on the history of Central Asia and Kazakhstan relates mainly to foreign policy and international cooperation within the New Great Game framework (Fingar, 2016; Menon, 2011). Additionally, the focus is being laid on threats to regional security and the potential of conflict in Central Asian (Donelli, 2012; Karimi, 2015). Besides participation in the New Silk Road project, Kazakhstan is forced to deal with the consequences of the international struggle for indigenous energy resources and with the conflict of interests between the US, China and Russia (McGlinchey, 2016; Patnaik, 2016). Obstacles delaying the solution of the above problems take roots in the complex historical past of the Central Asian nations.

The current study of the ethnogenesis of Kazakhs involves research papers, travel notes, memoirs and early literature in rare instances. This study argues that works written in Mamluk-Kipchak language play a great role in the social, ethnic, political, cultural, and linguistic research on the history of the modern Turkic people (Aubakirova, Jubatova, Mustafayeva, Mukhitdinov, \& Zhiyekbayeva, 2015; Kiynova, Sansyzbayeva, Akhmetzhanova, Mussabekova, \& Muratbayeva, 2018). The European written sources are also of great importance.

The historiographical analysis showed that the latest problems in international relations have originated from an ethnic identity of the nation. Hence, exploring these problems in the context of ethnology will allow a better understanding of the most efficient escapes. European writers of the middle of XIII to the beginning of XX centuries contributed works that are valuable in terms of such an exploration. 
This study begins with a critical analysis of multiple written sources, and the discussion part shows the contrast between the ethnogenesis of Kazakhs and that of the Turkic and Slavic ethnic groups.

\section{Results and Discussions}

The exploration of the history of Central Asia and the ethnic Kazakh community took many centuries, and many works were devoted to this matter. The most valuable pieces of writing related to Iran and Central Asia in general. These works were written by European travellers, monks, diplomats and merchants (Giovanni da Pian del Carpine, William of Rubruck, Marco Polo, Ruy González de Clavijo and others) in the XIII-XV centuries and by Western European scholars (Burns, Vambery, Wood, Meyendorf, Olufsen, Ghedin, Skylar Uvalfi) in the XVI-XIX centuries.

Pope Innocent IV sent a mission headed by an Italian monk Giovanni da Pian del Carpine to Mongolia in 1245 . The mission's goal was to spread Catholicism among Turks and Mongols. Carpine passed through the following territories, leaving a detailed report on his journey: the South of Russia, the North of Khorezm, and the Kazakh lands (Semirechye, Tarbagatai). Another ray of light was shed onto the matter by William of Rubruck, who participated in the crusade of King Louis IX of France to Palestine. Rubruck narrated about the existence of Turks and their permanent dwellings. "They also make pyramids to the rich, that is to say, little pointed structures, and in some places, I saw great tiled covered towers, and in others stone houses, though there were no stones thereabout," he wrote (Rockhill, 2017: 25).

Marco Polo provided a detailed description of the life of the Turkic nations that encompassed a broad range of topics from dwelling to cattle breeding and migrations. Marco Polo used the term "Tatars" in his works, referring to Turks in general. Until the XIX century, these two terms were often regarded as synonyms. According to Marco Polo, the diet of "Tatars" consisted of coarse food, especially meat and milk (Brooks, 2008).
Regarding the origin of the Kazakhs, Witten arbitrarily marks their proximity to the Tartars. This can be explained by the fact that the term "Tatars" in Russia and Europe has been generally applied to the Turkic ethnic groups until the beginning of XX century. Additionally, Witten misplaced the Kazakh ethnic group in the region between the Yenisey River and Mongolia.

In the early 1740s, British researchers Hogg and Thompson visited the Kazakh lands. Their reports, however, contained a number of unforgivable inaccuracies. For instance, the major rivers, the Amu Darya River and the Syr Darya River, were not distinguished.

In the 1760s-1770s, Swedish researcher Falk visited Astrakhan, Orenburg, Omsk, Petropavlovsk, Semipalatinsk, and many Kazakh auls (villages), where he collected some interesting ethnographic materials. His findings were later published in his paper about the Kyrgyz steppe (Falk, 1825).

In 1776, Johann Gottlieb Georgi went on a trip across Kazakhstan. His work "Description of all nations of the Russian Empire, their way of life, religion, customs, homes, clothing and other peculiarities" (Georgi, 1776) is indicative of his interest in the Kazakh people. His work provides empirical material that is rich but somewhat generalised, and conclusions he drew are not entirely accurate or methodologically sound.

Despite the undoubted successes of ethnographic studies on Kazakhs, foreign scholars have encountered some difficulties during their research activity. Back in the midXVIII century, Tatishchev (1769) noted that European explorers have mistakenly referred to Kazakh, other Turkic and non-Turkic population of the East as Tatars. Furthermore, the territory extending towards the east of the Volga River was misnamed the Great Tartary. Tatishchev (1769) categorised Kazakhs to the "Scythian" group, besides Bashkirs, Karakalpaks, Tatars, and Turkmens. In the foreign literature, Turks and other Eastern ethnic groups (Mongols, Manchus, etc.) were referred to as a single ethnic group of Tatars (Zhanbossinova, Karibaev, Atantayeva, Kulshanova, \& Shaimerdenova, 2019). 
The most evident misconceptions may be found in the "General history of Huns, Mongols, Turks and other Western Tartars" by Joseph de Guignes, also known as the "Histoire générale des Huns, des Mongoles, des Turcs et des autres Tartares occidentaux." His opinions dominated in Western Europe throughout the XIX century, although the classification he applied to nations was based on the political divisions of that time, rather than ethnic origins (Masanov, 1966).

In Paris in 1784, LeClerc published his treatises called "A Physical, Moral, Civil, and Political History of Ancient Russia" (1783-1784) and "A physical, Moral, Civil, and Political History of Modern Russia" (1783-1785). These studies contained so many inconsistencies and mistakes that Boltin wrote two volumes of refutation to him. LeClerc argued about an intense relationship between Kazakh people and the Russian Empire. Boltin (1788) responded to these claims by saying that "Kyrgyz people were never angry with Russia." LeClerc referred to nomads as savages who need cultural reeducation, while Boltin provided scientific and objective arguments.

Meyendorff (1885) conducted an excessive study on the Kazakh national character. Despite the literary style of writing, his work contributed to the ethnology of the Kazakh nation. In the 1830-1840s, Gregor von Helmersen, Alexander von Humboldt, and an English explorer Atkinson visited Turkestan and collected a bulk of unique materials about the Kazakhs (migrations, division of labour between men and women, noble and ordinary people clothing). Later, in 1865, Atkinson, Middendorff, and Rada travelled across Siberia and the neighbouring countries of Central Asia. Reports, which they brought from the journey, were a vivid portrayal of the nomadic lifestyle of the Kazakhs.

The famous Hungarian scholar Arminius Vambery noticed a fundamental difference between Kazakhs and Kyrgyzs. According to him, the name "Kyrgyz" is mistakenly associated with all Kazakhs who lived in the southern part of the Khanate of Kokand. This suggests that those researchers, who are deeply engaged in the ethnography of the region, distinguish between
Kazakh and Kyrgyz ethnic groups. Vambery contributed plenty to the research on Turkic ethnic groups and the Kazakh ethnic community in particular. He wrote about faith, traditions, customs, and mentality of the peoples, emphasising the nationhood of the Kazakh ethnic group, which formed despite the extensive resettlement of its members.

In 1874, Friedrich von Hellwald published a work titled "The Russian in Central Asia" in which he described the life, culture, dwellings, clothing, food, and beliefs of the nomads. Referring to the territory occupied by Kazakhs, he noted that this ethnic group was mostly nomadic and inhabited the vast steppe area extending from the Urals to the Balkhash Lake, from the Caspian Sea to the Altai Mountains (Hellwald, 1874).

In 1876, the French Ministry of Public Education sent an explorer Ujfalvy de Mezőkövesd on a scientific expedition to Central Asia where he spent two years travelling across the Kazakh lands. The explorer visited Semirechye, the settled agricultural areas in the Syr Darya basin, the North East of the Aral Sea, and cities of Turkestan, Chimkent, Tashkent, and Samarkand. After his journey, he compiled a collection of documentary materials entitled "Syr Darya, Zeravshan and the country of seven rivers of Siberia" ("Le Syr-Daria, le Zerafchan et le pays des Sept-Riviéres de la Sibérie") and published it in 1879. His work describes the nomadic lifestyle of the population of southern Kazakhstan and Semirechye; expresses exciting opinions about the identity of nomadic steppe dwellers, the Uzbeks; and vividly describes the Syr Darya settlements with their cultural attractions. The work also provides details about clothing, food, and shelters of nomadic Kazakhs alongside the information about the labour activity of men and women (Ujfalvy de Mezőkövesd, 2006).

At the end of the XIX century, Brehm published a work about horse veneration in the Kazakh community that was ethnographically appealing. In his essay "Life in the North and South from the pole to the equator," he highlighted the crucial role of horses in the life of the Kazakh people and this opinion was consistent with the views of 
most researchers about the Kazakhs as inborn magnificent equestrians and shepherds.

Swede Hedin (1899) went on a journey through the Asian steppes at the end of the XIX century. Afterwards, he wrote a book titled "In the heart of Asia. Pamir, Tibet, Eastern Turkestan." He noted that Kazakhs were semi-wild but capable, healthy and good people, who struggled for freedom and existence. Hedin faithfully described the life of the Kazakhs while drawing readers' attention to details. For instance, he translated the word "Cossack" as "brave", linking it to self-designation of the Kazakhs.

In 1903-1909, a German researcher Richard Karutz conducted ethnographic research on the Mangyshlak Peninsula in western Kazakhstan. Based on one's own observations and research, Karutz wrote an article "From Lubeck to Kokand" and a monograph "Among the Kirgiz and Turkmens of Mangyshlak." In his notes, the German scholar described scenes of people's everyday life and the migration history of the Central Asian ethnic groups. He also threw light onto the relations between the ethnic groups in the region. The scholar contributed many details about the Kazakh life. Among them are his descriptions of the Kazakh dwellings. According to him, a tent was a wooden construction, covered outside with mats and felt mats, and consisting of three elements: a framework for walls (kerege), a dome made of poles (ukes or unines) and exhaust wrap (tamarac) (Karutz, 1910).

The Sweden scientist Swanberg depicted the lifestyle, culture, economy, class and tribal structure of the Kazakhs living in the Middle Horde. This group of tribes consisted of about 3.000.000 people, of whom over 1.000 .000 were nomads of the steppes.

In 1921, the French ethnographer JosephAntoine Castagné published a book titled "Les tamgas des Kirghizes (Kazaks)." He drew particular attention to the beliefs of the Kazakhs, which were different from those of Islamic Turkic nations (Tatars, Uzbeks, etc.). Castagné touched upon those elements of the Kazakh religion that originated from shamanism, e.g., the performance of ritual sacrifice in the onset of a disease. Overall, Castagné offered a description of Kazakh religion as a versatile and spiritual healing practice (Castagné, 1921).

The Kazakh minorities settled in Xinjiang, China, continue to live their traditional nomadic and semi-nomadic ways of life. This allows one to explore those elements of material and spiritual culture that continue to be around despite the mass transition of other groups to Kazakh citizenship.

A comprehensive study on the ethnogenesis of Kazakhs and the neighbouring Turkic and Slavic ethnic groups is not possible without the previous findings (Bugybaykizi et al., 2015). When studying the ancient history of Kazakhs, historians told what has already been told, serving the retold as a discovery. The field lacked independent research. Naturally, new historians repeat the mistakes made by previous historians and do not make contributions to historical research. Consequently, the historiographical tradition is supported by the flow of views regarding the Kazakh history that are far from objective and distorts the understanding of the Kazakh people.

The European research contains a thorough justification of scientific materials and conveys a great deal of Kazakh folklore (that is, fables, proverbs, sayings, legends, fairy tales, and lullabies). These studies describe the originality of traditional Kazakh dwellings (yurts), their structure and appearance. They open the door to the world of ancient architecture, art, agriculture, household utensils, clothing, and crafts of nomadic and settled communities. The European historians, anthropologists, geographists and linguists were first to attempt to answer the disputed question of the Kazakhs' origin by exploring the role of nomadic Kazakhs in the history of Central Asia, their economy and social relationships.

\section{Conclusions}

The study performed an analysis of works from Western European explorers. As it turned out, Western European explorers were utterly unfamiliar with the life and culture of Kazakhs and other Turkic nations and conveyed 
somewhat subjective views. Their works contain factual inaccuracies, unverified information and speculations. Such a drawback could result from a lack of consistency in materials that were collected during their journey across the nomadic land and from the poor knowledge of local languages. The verification of printed information was challenging, especially in the XIII and XVII centuries, due to a limited range of insights and a minimal number of sources available. The records of events and facts were made sporadically and haphazardly for objective and subjective reasons.

Nevertheless, these studies provide shreds of evidence on the ethnogenesis of the Kazakh ethnic group. Researchers attempted to understand more deeply the spiritual world, history, life, culture, customs and traditions, rituals and beliefs of the Kazakhs. The content of their works is authentic and pinpoints cultural and spiritual values of the Kazakh people living in the middle of the XIII - the beginning of XX centuries. These works include ethnographic data about the past of the Kazakhs and other Turkic nations. European authors offered an enormous contribution to the ethnography and ethnology of Kazakhstan. They enriched the fields of anthropology, ethnic psychology, and pedagogy. These studies are rich in historical materials about Kazakhstan and other Central Asian countries. This research contributes to a better understanding of the events that took place in Eurasia in the Middle Ages and today. Multiple written sources published in English, German, French, Italian and other languages in the middle of XIII to the beginning of XX centuries opened an opportunity to familiarise with the ethnic history of the Kazakh people.

\section{References}

Aubakirova, K., Jubatova, B., Mustafayeva, A., Mukhitdinov, R., \& Zhiyekbayeva, A. (2015).

Written Manuscripts in Ancient Kipchak Language of 13-15th Centuries and their Research Problems in Kazakhstan.

Mediterranean Journal of Social Sciences, 6(5), 575-581.

https://doi.org/10.36941/mjss.2015.v6n5s1p57 5
Boltin, I. (1788). Notes on the History of Ancient and Modern Russia by Mr. LeClerc. St-

Petersburg: Mining School Printing House.

Brooks, N. (2008). The Story of Marco Polo. New York: Cosimo Inc.

Bugybaykizi, B. Z., Ushtanovna, Z. L., Rahmetovna, K. A., Tileubergenovna, S. S., Akzholovich, B. T., \& Ongarbekovna, B. G. (2015). Ethnographic Development of Kazakh Toponymy. Mediterranean Journal of Social Sciences, 6(4), 462-466. https://doi.org/10.5901/mjss.2015.v6n4s1p462

Castagné, J. A. (1921). Les tamgas des Kirghizes, Kazaks. Paris: E. Leroux.

Chan, Y. K. (2016). The Greater Game: Qing China in Central Eurasia. History Compass, 14(6), 264-274.

https://doi.org/10.1111/hic3.12314

Donelli, T. (2012). Ferghana as FATA? A post2014 strategy for Central Asia. Army War Coll Carlisle Barracks PA. Retrieved from https://apps.dtic.mil/dtic/tr/fulltext/u2/a56166 7.pdf

Falk, I. P. (1825). News of the Kyrgyz steppe. In Complete collection of scientific travels to Russia. Vol. 7. (pp. 5-28). Saint-Petersburg: Imperial Academy of Sciences.

Fingar, T. (Ed.). (2016). The new great game: China and South and Central Asia in the era of reforRedwood City: Stanford University .m .Press

Georgi, J. G. (1776). Beschreibung aller Nationen des Russischen Reichs, ihrer Lebensart, Religion, Gebräuche, Wohnungen, Kleidung und übrigen Merkwürdigkeiten (Description of all nations of the Russian Empire, their way of life, religion, customs, homes, clothing and other peculiarities). Saint-Petersburg: Müller.

Hedin, S. (1899). In the heart of Asia. Pamir, Tibet, Eastern Turkestan. St. Petersburg: S-Pb. Univ. Devrient.

Hellwald, F. V. (1874). The Russian in Central Asia. London: Tr. Wingman.

Islam, A. (2016). The Mongol Invasions of Central Asia. International Journal of Social 
Science and Humanity, 6(4), 315-319. https://doi.org/10.7763/IJSSH.2016.V6.664

Karimi, M. (2015). Rivalry of global powers in Central Asia after the Cold War. Geopolitics Quarterly, 10(4), 122-148.

Karutz, R. (1910). Among the Kirgiz and Turkmen in Mangyshlak. Saint-Petersburg: St. Petersburg Publisher.

Kiynova, Z. K. K., Sansyzbayeva, S. K., Akhmetzhanova, A. I., Mussabekova, U. E., \& Muratbayeva, I. S. (2018). Kazakhstan Realities in the Perception of Representatives of American Ethnolinguoculture. Space and Culture, India, 6(3), 71-81. https://doi.org/10.20896/saci.v6i3.370

Liedy, A. (2011). The Great Power Rivalry in Central Asia. Kennan Institute. Retrieved from: https://www.wilsoncenter.org/publication/thegreat-power-rivalry-central-asia

Masanov, E. A. (1966). Essay on the history of ethnographic study of the Kazakh people in the Soviet Union. Almaty: Nauka.

McGlinchey, E. (2016). Leadership Succession, Great Power Ambitions, and the Future of Central Asia. Central Asian Affairs, 3(3), 209225. https://doi.org/10.1163/2214229000303001

Menon, R. (2011). The New Great Game in Central Asia. Survival, 45(2), 187-204. https://doi.org/10.1080/00396338.2003.96885 81

Meyendorff, G. (1885). The journey from Orenburg to Bakhara. Turkestan Collection. Almaty: Nauka.
Morrison, A. (2015). Peasant Settlers and the 'Civilising Mission' in Russian Turkestan, 18651917. The Journal of Imperial and Commonwealth History, 43(3), 387-417. https://doi.org/10.1080/03086534.2014.94116 6

Patnaik, A. (2016). Central Asia: Geopolitics, Security and Stability. Routledge. https://doi.org/10.4324/9781315636894 Rockhill, W. W. (2017). The Journey of William of Rubruck to the Eastern Parts of the World, 1253-55: As Narrated by Himself. With Two Accounts of the Earlier Journey of John of Pian de Carpine. London: Hakluyt Society. https://doi.org/10.4324/9781315556420

Starr, F. (2015). Lost enlightenment : Central Asia's golden age from the Arab conquest to Tamerlane (Reprint ed). Princeton: Princeton University Press.

Tatishchev, V. N. (1769). History of Russia since ancient times. Moscow: Book on Demand Ltd.

Ujfalvy de Mezókövesd, K. J. (2006). Syrdarya Zeravshan. The country of seven rivers and Western Siberia. In History of Kazakhstan in Western sources of XII-XX centuries. (p. 179). Almaty: Sanat.

Zhanbossinova, A. S., Karibaev, M., Atantayeva, B., Kulshanova, A., \& Shaimerdenova, M. (2019). Socio-Cultural Adaptation of Repatriates of East Kazakhstan and Migration Attitudes of the Kazakhs of Mongolia. Space and Culture, India, 7(1), 154-169.

https://doi.org/10.20896/saci.v7i1.414 